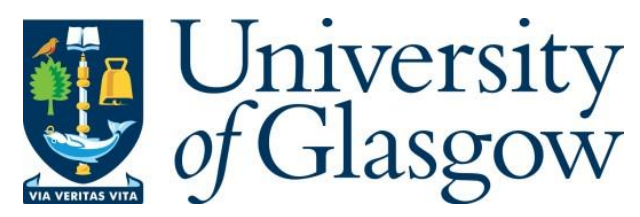

Liñeira, R. and Cetrà, D. (2015) The independence case in comparative perspective. Political Quarterly, 86(2), pp. 257-264.

There may be differences between this version and the published version. You are advised to consult the publisher's version if you wish to cite from it.

http://eprints.gla.ac.uk/219968/

Deposited on: 15 July 2020

Enlighten - Research publications by members of the University of Glasgow http://eprints.gla.ac.uk 


\title{
The Independence Case in Comparative Perspective
}

\author{
Robert Liñeira- University of Edinburgh and Centre on Constitutional Change \\ Daniel Cetrà - University of Edinburgh and Centre on Constitutional Change
}

\begin{abstract}
Scotland is not the only sub-state unit in Europe where relevant political actors make claims for independence. To generate insights on these independence demands, we compare the drivers, arguments and popular support for secession in Scotland, the Basque Country, Catalonia and Flanders. We argue that national identity, party politics and the economy are behind the independence demands, and the exact articulation of these elements varies from case to case. Currently, the most salient of the independence demands are the ones from Catalonia; Basque demands for self-determination are less prominent than in the past, whereas the demand for voting on independence is much less articulated in Flanders. Although the Scottish independence referendum has set a precedent for solving independence disputes, we argue that the possibilities of exporting the Scottish referendum experience to these cases are limited.
\end{abstract}

\section{Keywords}

Secession; Independence Referendums; Basque Country; Catalonia, Flanders; Scotland

Independence referendums in stable democracies are uncommon, and cases such as Quebec and Scotland are rare. However, there are a number of other places which witness relevant movements asking for independence from their state. The Scottish independence referendum has set a precedent for political actors who seek to channel their secession demands through an independence referendum. Pro-independence movements may use it to claim their right to hold a similar vote, and future attempts to get independence may be judged against the yardstick of Scotland.

How can we compare these different cases for independence? In this article we contrast the drivers, arguments and support for secession in Scotland, the Basque Country, Catalonia and Flanders. The aim is to look for similarities and differences in the case for independence across different sub-state units, to generate insight on independence demands and how to channel them. Why these cases? All of them share a salient and widespread debate on the possibility of secession in democratic and relatively affluent societies. They also share the existence of self-governing institutions within a federal or regional scheme in the EU context.

The article's structure is as follows. First, we address the question of the relationship between national identity and support for independence. Second, we examine the strength of nationalist parties in the different sub-state party systems and their basic constitutional strategies. Third, we explore the role played by the economy and economic grievances in 
the case for secession. We finally discuss the current proposals by the different nationalist movements and the possibilities of exporting the Scottish referendum model overseas.

\section{National identity and support for independence}

Conventional accounts tend to explain secessionism as a function of the identity-based distinctiveness of groups. Although demands for secession do not necessarily stem from cultural distinctiveness, national identity is usually considered the main driving factor of independence support. Evidence from Scotland, Catalonia, and the Basque Country shows that individuals who identify more strongly with the sub-state unit tend to be more in favour of independence. ${ }^{i}$ However, there are non-secessionist nationalist movements and citizens with exclusive sub-state identity who support enhance self-government institutions for their territories, but not full secession. This implies that a link between identification and pro-independence attitudes is by no means definite. National identity is neither a necessary nor a sufficient condition for the development of self-determination movements and the support to independence, although a distinctive identity is the strongest common factor across our cases.

At the individual level, national identity is regarded as a cause of independence support because it is a very stable political attitude that does not change easily in the short term. National identity is a consequence of socialisation and past experiences, and it conditions citizens' political attitudes in general and constitutional preferences in particular. It is the stable nature of national identity which makes it a good candidate to explain differences in support for independence across countries and individuals, but not changes in this support across time. ${ }^{\text {ii }}$

Further, the fact that individuals tend to maintain the national identity, early acquired, through their lives, makes generational turnover the main mechanism of societies' identity change, when new generations socialized under new identity patterns replace old generations. However, there is evidence that individuals change their national identities during their life course - even in short term periods ${ }^{\mathrm{iii}}$ - which forces us to qualify this notion of individual's national identity as something that affects the political process without being affected by it.

Scotland, the Basque Country, Catalonia, and Flanders have in common the existence of alternative national projects which affect -in different degrees- people's identities. This implies that a state identity, mainly promoted by state institutions, competes with a substate identity, promoted by various sub-state political and social actors. In fact, the existence of this sub-state alternative identity and national project is the main reason behind the setting up of self-governing institutions in all our 4 cases. Thus, all our substate units have in common the existence of dual identities which are spread in different degrees and with different intensities.

Figure 1 shows the distribution of these identities using a common indicator. All of them show that sub-state identities are more prevalent than state identities. Sub-state identity is 
especially widespread in the Basque Country. A third identifies as only Basques; together with those who think of themselves as mainly Basques, they form a majority of $55 \%$. In Scotland and Catalonia, exclusive sub-state identities are less prevalent than in the Basque case but the distributions lean towards Scottish and Catalan identities (53\% and 46\% respectively).

With the exception of Flanders, state identities are selected by a small minority. In fact, Flanders shows a more balanced distribution than the other 3 cases, although there is a slight leaning towards state identities: $27 \%$ identify themselves as only or mainly Flemish and $31 \%$ as exclusive or mainly Belgians. The most frequent identity is without any doubt the intermediate one, with $42 \%$ identifying as equally Flemish and Belgians.

\section{Figure 1. National identity in $2014^{\text {iv }}$}

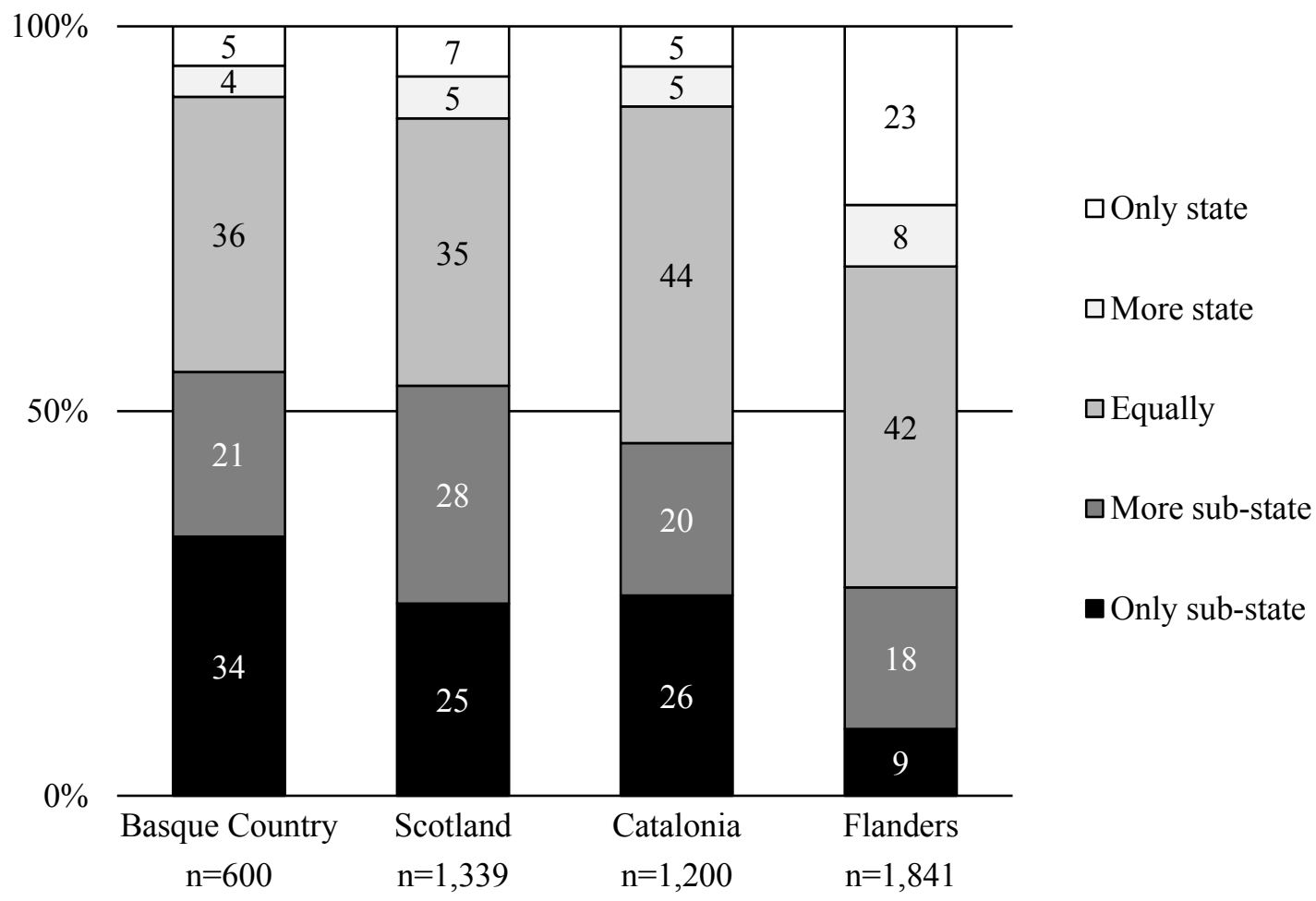

Note: with slight differences, the common question is: 'Which best describes respondent, on a scale from 'Sub-state not state' to 'State not sub-state'?'

The relationship between identity and support for independence is not a deterministic one: if support for independence was a mere function of national identity, we should expect the Basque Country to be the place with the highest support for independence, Flanders the one with the lowest, and Scotland and Catalonia somewhere in between. However, this is not exactly the case.

Table 1 shows the support for different constitutional arrangements in our 4 cases. Constitutional preferences in public opinion polls are more volatile than national identities, and susceptible to wording effects. Still, with the exception of Flanders -where 
only a minority supports more powers for the Flemish Parliament- there is clear support for enhanced self-government in the other 3 sub-state polities. Scotland and Catalonia show a similar distribution of preferences, being the two cases which show more widespread support for independence. The fact that the Basque Country is the place with more widespread sub-state identity but not more support for independence shows the necessity to add additional elements into the picture. The fact that constitutional preferences are more volatile than national identity also suggests that we need political and economic explanations to account for short-term changes.

Table 1. Constitutional preferences in $2014^{\text {iv }}$

\begin{tabular}{lcccc}
\hline & Scotland & Catalonia & Basque Country & Flanders \\
\hline No devolved Parliament & 6 & 4 & 6 & 4 \\
Less powers & n.a. & n.a. & n.a. & 20 \\
Status quo & 23 & 27 & 38 & 38 \\
More powers & 30 & 22 & 33 & 35 \\
Independence & 41 & 46 & 23 & 4 \\
\hline No Parliament - Status quo & 29 & 31 & 44 & 62 \\
More powers - Independence & 71 & 68 & 56 & 39 \\
\hline (n) & $(1,339)$ & $(1,200)$ & $(600)$ & $(1,841)$ \\
\hline
\end{tabular}

Note: The question wording and the alternatives offered to respondents vary significantly across the four cases.

\section{Support and strategies of the nationalist parties}

Identity is not the full story to account for independence support. Politics is important and, in particular, party politics. Decades of research on public opinion have persistently shown that parties provide citizens with cues which help them to establish their preferences. Parties, unlike issues or candidates, give continuity and structure to the political debate, and act as 'perceptual screens' through which individuals follow the political process. Consequently, party stances on constitutional options reflect but may also affect followers' constitutional preferences.

Our cases share some similarities. The party systems of Scotland, Catalonia, and the Basque Country are a mix of state-wide and non-state-wide parties, which means that nationalist parties compete for votes with parties that also stand for seats all over the state territory. In contrast, party systems in Belgium are divided along linguistic or community lines, which indicates that Flemish parties stand for different constituencies than Frenchspeaking parties. Since parties do not risk being sanctioned by voters from the other community, the dynamics of party competition are exclusively regional, pulling apart Flemish and Walloon parties and electorates.

An element that all 4 party systems share is the existence of a clear pro-independence party: the Scottish National Party (SNP), the Republican Left of Catalonia (ERC), Sortu, and the Flemish Interest (Vlaams Belang). There are also smaller parties which support independence. The Popular Unity Candidacies (CUP) in Catalonia and the Greens in 
Scotland have parliamentary representation and support independence. However, independence is not their main issue or they are not big enough to dispute and claim the issue ownership of the independence cause. Indeed, the SNP is unique in the sense that it does not have to face significant competition from another nationalist party. The other 3 cases show a more significant division between nationalist parties seeking independence and parties seeking more self-government within their current state. Sub-state nationalism is a dimension of electoral competition in the other three.

In the case of the Basque Country, the Christian-democratic Basque Nationalist Party (EAJ-PNV) has always been the main nationalist party. It has been the incumbent party in Basque self-government institutions for most of the time since the first regional elections in 1980. It has been elusive about the independence question, alternating between pro-self-government and pro-sovereignty positions. During this period, it has always competed with the Basque radical nationalist left, which constitutes the main advocate of independence. The party labels of this movement have frequently changed, and they have also experienced outlaw periods because of the ties with the violent organisation ETA. Their current party label is Sortu, which stood in the last Basque election for the Basque Country Unite coalition (EHB, a coalition of Alternatiba, Aralar, Eusko Alkartasuna and Sortu). Currently, the EAJ-PNV heads a minority government whereas EHB holds 21 of 75 seats. The former will seek the support of the latter in order to deliver its proposal of a new political status for the Basque Country in 2020.

The main nationalist party in Catalonia since the advent of democracy has been the coalition Convergence \& Union (CiU), which has enjoyed the presidency of Catalan institutions for 23 years since the first regional elections in 1980. It has been historically associated with the promotion of self-government within Spain, but recently stood for the holding of a referendum which includes the independence option, being ambivalent about its positioning on the question. CiU is a coalition between two parties: Democratic Convergence of Catalonia (CDC) and Democratic Union of Catalonia (UDC). The former currently tends to be in favour of independence, whereas the latter supports a confederation scheme. However, it is unclear how unanimous these stances are within the parties. CiU currently holds a minority government with the parliamentary support of the pro-independence ERC, which holds 21 seats out of 135 .

In Flanders, the main nationalist party is the New Flemish Alliance (N-VA), which has experienced a spectacular rise in the past few years. Founded in 2001, the N-VA supports confederalism in the short term and independence in the long term. It is currently the leading party of the Flemish coalition government and member of the Belgian federal coalition government. The pro-independence and far-right Vlaams Belang (previously named Vlaams Blok) was the main nationalist party in Flanders in the past, but it is now severely damaged by the success of the N-VA. There is a tacit cordon sanitaire around the Vlaams Belang, which means that the party is blocked from accessing political power by the rest of the parties due to its extremist ideology. Thus, in practice the N-VA is the only Flemish nationalist party with actual capacity of political influence. 
Whereas national identity has a strong exogenous influence on individual's attitudes towards independence, party stances on constitutional options may also influence individual's constitutional preferences. However, identity and party politics are not the whole story. Economics may also colour the case for independence and influence the popular support for it.

\section{The economic case for independence}

The economy, and economic grievances in particular, are used as explanations of the existence of support to secession. The dominant prediction in the literature is that the regions or groups that are better off than the rest of the country will have a higher likelihood of demanding secession since they often subsidise poorer regions. ${ }^{\mathrm{V}}$ The mechanism is quite straightforward: by separating, they would have more disposable resources because they would no longer be subject to fiscal imbalances with respect to the rest of the state. They could also provide more public goods and do so more efficiently, as a consequence of an increased homogeneity of preferences in a smaller region. $^{\text {vi }}$

The role that the economy plays in the case for secession shows similarities and differences across our cases. Whereas the Basque Country, Catalonia, and Flanders are relatively wealthier with regards to the rest of Spain and Belgium, this is not the case of Scotland. Table 2 gathers the GDP per capita in our four cases, and puts it in relation to the GDP of the United Kingdom, Spain, and Belgium. The third column shows that the GDP of Scotland is 7\% less than the overall UK GDP, the Catalonia and the Basque Country are 17 and 34\% over the Spain GDP per inhabitant. Flanders is roughly the same than the overall position of Belgium, which is composed of three regions. Brussels is by far the richest region in Belgium (62,000 GDP per capita), whereas Wallonia is the poorest $(24,600)$. Flanders' GDP per inhabitant is $37 \%$ higher than Wallonia's.

In Scotland, even if there have been some attempts to build an economic case for independence around oil and tax revenues, the argument that, by separating, there would be more disposable resources, is difficult to convey. Additionally, the economic argument to support secession is not employed in all cases. It is used in Catalonia and Flanders, but less often in the Basque Country.

Table 2. Socioeconomic characteristics ${ }^{\mathrm{vii}}$

\begin{tabular}{lrrr}
\hline & $\begin{array}{r}\text { Population } \\
\text { (Millions) }\end{array}$ & $\begin{array}{r}\text { Nominal GDP } \\
\text { 2011 in Euros }\end{array}$ & $\begin{array}{r}\text { Ratio sub-state / state } \\
\text { GDP per capita 2011 }\end{array}$ \\
\hline Scotland & 5.2 & 26,200 & 0.93 \\
Catalonia & 7.3 & 26,600 & 1.17 \\
Basque Country & 2.1 & 30,500 & 1.34 \\
Flanders & 6.3 & 30,100 & 1.00 \\
\hline
\end{tabular}


Until recently, Catalan nationalism mainly focused on linguistic and cultural issues; the recognition of national distinctiveness, and the promotion of the Catalan language, were the main goals of the nationalist movement. Economic issues have gained salience in recent years. The perception of economic grievance and, specifically, the idea that the difference between Catalonia's contribution and what it receives in transfers and investments from the Spanish government is too large, has fuelled a sense of grievance across Catalan elites and a significant portion of the Catalan public. This dispute has also fired-up discussions between the Catalan and the Spanish governments about the amount of the Catalan fiscal deficit. Thus, the parties favouring secession or greater devolution in Catalonia have agreed on the perception that the fiscal treatment received by the Catalan government is unfair, and that it limits Catalonia's ability to develop stronger social policies and promote economic growth. Under these circumstances, secession has often been presented as an alternative that would increase the available budget of the Catalan government and remove obstacles to desired policies.

In the Basque case, the economic argument for independence is largely absent. The main reason is that it enjoys a beneficial fiscal agreement. Under the concierto económico, the three Basque historic territories that currently form the Basque autonomous community set and collect most taxes and pass on a share to the Spanish government for common services. This advantageous fiscal arrangement can be seen as a structural difficulty for Basque independence, given that a case of economic grievance similar to the one in Catalonia cannot be made.

As in the Catalan case, the cultural and language domain was very salient in Flanders. Although a degree of controversy still remains in the Flemish periphery of Brussels, the cultural case is now less prominent in favour of the economic one. The economic argument is built around two related ideas. First, a sense of grievance over transfers to Wallonia and a critical attitude to the generous Walloon welfare policies. Second, the notion of a democratic deficit, which refers to the idea that Flanders' pro-liberal policy preferences (compared to the more 'pro-socialist' Wallonia) cannot be delivered due to the consociational scheme of federal institutions. More powers for the Flemish region are deemed necessary to make congruent policy preferences with policy outcomes in Flanders.

The different policy preferences argument is also present in Scotland but, in this case, the argument comes from the other side of the political spectrum: independence would be used to promote a more social-democratic policy agenda than the one preferred by the UK government. The SNP makes a case for Scottish independence that largely focuses on welfare and social policy, connecting independence to social fairness and drawing on myths of egalitarianism and the notion of democratic deficit (see articles by Malcolm Harvey, Kirstein Rummery and Craig McAngus, and Sheila Riddell et al., in this volume).

\section{Discussion: independence referendums beyond Scotland}


Independence referendums will continue to be rare events. However, the Scottish experience has helped to normalise them, becoming a potential yardstick for solving future secession disputes (see Stephen Tierney in this volume). This is so because of the fairness of the Scottish referendum process, the general spirit of mutual respect and cooperation achieved between the two sides, the level of engagement with the debate by the public, and the acceptance of the results by all parties.

There are 4 characteristics that future independence processes may be asked to mirror, from the Scottish model, to be considered legitimate. First, the right to claim an independence referendum must derive from a popular mandate. Second, an independence decision must be decided directly by citizens via referendum. Third, the terms of the referendum should be agreed between the state and the sub-state governments; the way to address independence disputes should be settled by a bilateral agreement within domestic law. Fourth, the referendum has to pose a clear question to citizens.

In Scotland, the initiation of the referendum was agreed by the UK government after the SNP won a majority at the 2011 Scottish Parliament election, advocating for an independence referendum in its party manifesto. In addition, the referendum as instrument had already been used in 1979 (there was a small Yes majority, but it did not reach the required threshold of $40 \%$ of the electorate), setting a precedent for the 1997 referendum that approved the establishment of a Scottish Parliament, and the 2014 referendum that went a step further to ask about independence. Finally, the terms of the referendums were set at the Edinburgh Agreement between the UK and the Scottish governments, which included the clear question condition and its approval by the Electoral Commission.

In Catalonia and the Basque Country there have been attempts to hold referendums on self-determination by their sub-state governments. Both sub-state units have in common with Scotland the use of the referendum instrument to decide on self-government issues. In contrast with Flanders, where the constitutional reforms that led to the setting of the Flemish Parliament were passed by a parliamentary vote and not by a popular one, Catalonia and the Basque Country set and reformed their respective self-government institutions by mandatory referendums. However, to hold a referendum that includes the possibility of independence is problematic because the Spanish constitution does not contemplate the possibility of secession nor any other sovereign nation than the Spanish people as a whole.

The most serious of the attempts to hold a referendum on independence outside Scotland has been the recent voting in Catalonia. On November 9 there was a non-binding vote on independence, promoted by the Catalan government and opposed by the Spanish government. The vote, which came to be known as 'participation process', was more an act of protest by the pro-independence side than a decisive test on the issue of secession. Voters were asked two questions: whether Catalonia should be a state and, if they replied yes, whether it should be an independent state. The Catalan government estimation is that 
around $36 \%$ of Catalan residents turned out to vote. Results showed that $80.7 \%$ voted yes to both questions, $10 \%$ voted yes to the first question and no to the second, while $4.5 \%$ voted no. The next step in this process could be what has been called by the Catalan government a 'plebiscite election', where pro-independence parties would stand for the next parliamentary election with a joint candidacy, with independence as the single point in the candidacy manifesto. This strategy is currently under discussion by the interested parties.

The vote in Catalonia was the result of an intense mobilisation period by selfdetermination supporters. The main trigger was the political dissatisfaction generated by a failed constitutional reform of the Catalan statute of autonomy. After being passed by the Spanish and Catalan Parliament, and ratified by the Catalan people in a mandatory referendum in 2006, the statute was taken to the Constitutional Court by the Popular Party (PP), the main opposition party to the Spanish Socialist government at the time. The Constitutional Court ruling in 2010 amended the statute, decreasing further the powers granted by the approved version: 14 articles were declared unconstitutional, several were subjected to reinterpretation, and the statement in the preamble that Catalonia is a nation was explicitly described as without legal standing.

This outcome was perceived, by large sections of the Catalan population, to be an illegitimate resolution because: only 10 of the 12 Constitutional Court magistrates voted on the ruling because one member had died without a successor been appointed; the authority of another member was challenged; and, the term of three other members had already expired when the decision was made.

Still, any reform to enhance self-government and the recognition of Catalonia's national distinctiveness looked less likely, damaging the political opportunities of those groups in favour of a federal reform of the constitutional framework, but giving momentum to promoters of overcoming the constitutional framework. The perception that the usual constitutional reform process could not be used for this purpose was accentuated by the PP's ample victory at the 2011 general election. The polarisation of party stances has helped make the independence issue ever more salient. Also, public opinion has shifted, from an overwhelmingly pro-autonomy position to an increasingly pro-independence stance. From 2006-14, the proportion that chose an independent Catalan state in a multioption question has risen from 14\% in 2006 to around 45\% in 2014.

The Basque government also tried to agree a constitutional referendum with the Spanish government under the so-called Ibarretxe Plan, which was promoted by the PNV Basque president of the time and rejected by the Spanish Parliament in 2005. The party's demands for a constitutional referendum are now less salient. Drawing inspiration from the Scottish referendum and the Catalan mobilisation, a recently created civil society organisation called 'It's in our hands' (Gure Esku Dago) organises events that aim to push for a referendum. However, the present stance of the PNV is a new political status for the Basque Country, which is an ambiguous notion that basically pretends to protect the 
powers of Basque institutions and to establish a bilateral political relationship with the Spanish government. The emphasis on bilateralism is an old demand by Basque nationalism, and it was evident in the 'co-sovereignty' proposal of the Ibarretxe Plan. ${ }^{\text {vii }}$

In contrast to the other cases, public support for independence in Flanders is minimal, and political efforts to promote a secession referendum have been largely absent. In fact, the current territorial proposal by the main nationalist party (N-VA) is further decentralisation (confederalism). Belgium would have two autonomous entities Flanders and Wallonia - and a bilingual capital, Brussels. The idea of confederalism partly derives from the 'problem' of Brussels, today a basically French-speaking city in historical Flemish territory that Flemish parties do not want to abandon. Flemish nationalists were reluctant to accept the creation of the Brussels Capital Region (1989) in the first place, for fear that it would align with the mostly French-speaking Walloon region. Under this plan, the Belgian parliament and government would disappear and be replaced by a co-ordinating state authority that would not be directly elected. It would retain control over the army and diplomacy, but key issues such as social security, tax and labour policy would be transferred to Flanders and Wallonia. Thus, rather than a referendum on independence, a progressive hollowing of the Belgian state to the benefit of the regions seems the most likely future scenario.

In sum, identity, politics, and the economy are behind the independence claims in Europe, although the precise articulation of these elements is case-specific. The most salient of these claims are now the ones from Catalonia; Basque demands for self-determination are less prominent than in the past, whereas the demand for voting on independence is much less articulated in Flanders. In any case, it is far from certain that there would be a new independence referendum in any of these places. No relevant actor in Flanders is pushing for it, whereas to hold such a referendum in Spain would require a change in the conception of the constitution and an agreement between governments that now looks unlikely. 


\footnotetext{
${ }^{i}$ McCrone, David, and Lindsay Paterson. 2002. "The Conundrum of Scottish Independence." Scottish Affairs 40(1): 54-75; Serrano, Ivan. 2013. "Just a Matter of Identity? Support for Independence in Catalonia." Regional \& Federal Studies 23(5): 523-45; Costa-Font, Joan, and Ramon Tremosa. 2006. National Identity and the Preference for State Opting-Out in the Basque Country. Working Papers in Economics, Universitat de Barcelona.

ii Blais, André, and Richard Nadeau. 1992. "To Be or Not to Be Sovereigntist: Quebeckers' Perennial Dilemma." Canadian Public Policy / Analyse de Politiques 18(1): 89-103; Howe, Paul. 1998.

"Rationality and Sovereignty Support in Quebec." Canadian Journal of Political Science/Revue canadienne de science politique 31(1): 31-59.

iii Hierro, María José. 2012. "Change in National Identification. A Study of the Catalan Case." PhD dissertation, Universidad Autónoma de Madrid.

iv Sources: For the Basque Country, Euskobarómetro (November 2014); For Scotland, Scottish Social Attitudes Survey (2014); For Catalonia, Political and Social Sciences Institute (ICPS) poll 2014; For Flanders, Kris Deschouwer, Lieven De Winter, Min Reuchamps, Dave Sinardet \& Jérémy Dodeigne, "Identities, institutional preferences and voting behaviour in Belgium". Belgium: the State of the Federation (Third Edition), Brussels, December 19, 2014.

${ }^{v}$ Bartkus, Viva Ona. 1999. The Dynamic of Secession. Cambridge: Cambridge University Press; Hechter, Michael. 2001. Containing Nationalism. Oxford: Oxford University Press.

vi Alesina, Alberto, and Enrico Spolaore. 2005. The Size of Nations. Cambridge, MA: MIT Press.

vii Source: Eurostat. http://epp.eurostat.ec.europa.eu/cache/ITY_PUBLIC/1-27022014-AP/EN/1-

27022014-AP-EN.PDF

viii Lecours, André. 2007. Basque nationalism and the Spanish state. Reno: University of Nevada Press.
} 